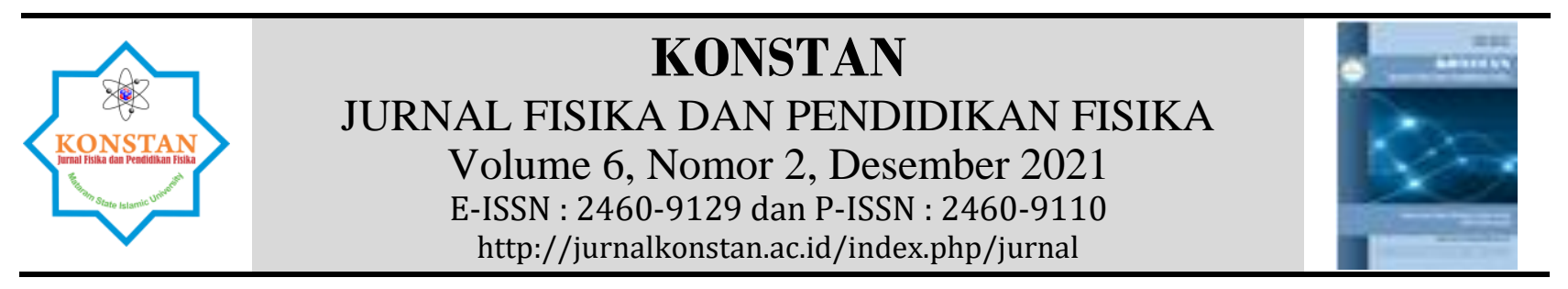

\title{
Studi Mitigasi Bencana Gempabumi Berbasis Kearifan Lokal di Sekolah Dasar Pulau Lombok
}

\author{
1)Syahrial Ayub, ${ }^{2)}$ Kosim, ${ }^{3)}$ I wayan Gunada, ${ }^{4)}$ Muhammad Taufik \\ Universitas Mataram, Jl. Majapahit 62 Mataram, NTB, Indonesia
}

*E-mail korespondensi: syahrial ayub@unram.ac.id

\begin{abstract}
Info Artikel: Abstract
Dikirim:

25 Maret 2021

Revisi:

14 April 2021

Diterima:

17 Mei 2021

Kata Kunci:

Kearifan lokal masyarakat

Lombok,

Mitigasi bencana

gempabumi,

Sekolah dasar

Pulau Lombok banyak memiliki warisan leluhur berupa kearifan lokal yang sangat berpengaruh dalam hal mitigasi bencana gempabumi. Penelitian ini bertujuan memaparkan apa adanya kearifan lokal dan kebijakan yang berkaitan dengan mitigasi bencana gempabumi berbasis kearifan lokal di SD Negeri 6 Mataram. Penelitian ini melibatkan kepala sekolah, guru, peserta didik dan penjaga sekolah. Data dikumpulkan melalui wawancara mendalam, observasi, focus group discussion (fgd), dan studi dokumen. Hasil penelitian mendapatkan kearifan lokal masyarakat Lombok terhadap mitigasi bencana gempabumi adalah : (1) keyakinan bencana gempabumi adalah ketetapan dari Allah SWT, (2) mitos telaga lindur yang menimbulkan kesadaran pentingnya hidup berdampingan dan harmonis dengan alam untuk menghindari terjadi bencana, (3) tanda fisik dan metafisik, (4) musyawarah dan mufakat, (5) gotong royong, (6) kentongan bambu, dan (7) desain rumah adat Lombok untuk mitigasi bencana. Kearifan lokal ini memberikan inspirasi bagi mitigasi bencana gempabumi di sekolah. Implementasinya adalah: (1) desain bangunan di sekolah, (2) informasi kebencanaan melalui mading, poster, spanduk dan lainnya. Dalam bentuk non struktural dilakukan : (1) sosialisasi, (2) integrasi materi mitigasi bencana gempabumi pada pembelajaran di kelas, (3) koordinasi antara sekolah dengan lingkungan sekitar. Jadi kearifan lokal yang dimiliki masyarakat Lombok berdampak positif terhadap mitigasi bencana gempabumi di pulau Lombok.
\end{abstract}

(C) 2021 Universitas Islam Negeri Mataram

\section{PENDAHULUAN}

Kearifan lokal merupakan bagian dari budaya suatu masyarakat yang tidak dapat dipisahkan dari bahasa masyarakat itu sendiri. Kearifan lokal (local wisdom) biasanya diwariskan secara turun temurun dari satu generasi ke generasi melalui cerita dari mulut ke mulut. Pada gempa Lombok 2018, relawan menyebutkan sejumlah rumah adat (rumah adat Senaru dan Batu Layar dan lainnya), berbahan kayu di pulau lombok, masih berdiri kokoh meski diguncang gempa tektonik 7 skala righter, minggu 5 Agustus 2018 [1]. Masyarakat Lombok memiliki kearifan budaya lokal ketika menyadari mereka hidup di sekitar ring of fire. Rumah adat sasak, merupakan rumah tradisional suku sasak yang berada di pulau Lombok. Rumah adat sasak terdiri dari 2 jenis yaitu Bale Tani dan Lumbung. Bale Tani adalah bangunan yang dipergunakan sebagai tempat tinggal, dan Lumbung adalah bangunan yang biasa digunakan untuk menyimpan padi hasil panen atau segala kebutuhan. Ada beberapa keunikan pada rumah adat suku sasak Lombok yang membuatnya unik dan kuat dari goncangan gempa, yaitu ; (1) memiliki berbagai tipe bangunan yang disesuaikan dengan peruntukkannya seperti pejabat desa, orang tua dan yang sudah berkeluarga yang terbuat dari kayu, 
dinding dari anyaman bambu, dan atap dari daun alang-alang kering; (2) lantai rumah terbuat dari tanah liat dan dipel dengan kotoran sapi/kerbau, kotoran sapi/kerbau diyakini dapat mengusir serangga; (3) terbuat dari anyaman bambu, sehingga ringan kokoh, kuat, dan tahan akan guncangan; (4) atap rumah terbuat dari alang-alang yang bentuknya menyerupai gunungan. Seperti anyaman bambu, alang-alang merupakan bahan yang ringan dan tahan akan guncangan gempabumi. Konstruksi bangunan dengan mengedepankan kearifan lokal menggunakan kayu justru menjadi penyelamat ketimbang bangunan permanen yang tidak mengikuti kaedah bangunan konstruksi tahan gempa. Struktur berugak menyerupai semacam pondok kecil tanpa dinding, yang juga terbuat dari bambu/kayu dan alang-alang juga merupakan bangunan tradisional masyarakat Lombok yang tahan gempabumi. Masyarakat Lombok memiliki khazanah pengetahuan tradisi mitigasi bencana mitos telaga lindur yang memiliki tuah sebagai penjaga sekaligus pembawa bencana bagi manusia. Pengetahuan tradisi telaga lindur sudah membumi dikalangan masyarakat Lombok sebagai wadah untuk menyampaikan pesan tentang kelestarian alam dan harmonisasi alam dengan manusia [2]. Ulah manusia yang merusak lingkungan, terjadilah bencana alam gempabumi. Artinya mitos telaga lindur memberikan pesan tentang keseimbangan dan harmonisasi manusia dengan alamnya yang harus dijaga dan pelihara dengan baik. Jika alamnya rusak, maka bencanapun akan menimpa manusia. Mitos telaga lindur juga, merupakan suatu upaya untuk menahan atau mengurangi kerusakan terhadap alam adalah satu rangkaian yang tidak dapat dipisahkan satu sama lain [2]. Masyarakat Lombok dikenal sebagai masyarakat yang ramah dan suka bermusyawarah dalam mencari pemecahan permasalahan bencana gempabumi dan secara gotong royong dalam mengatasinya. Kearifan ini sudah sangat melekat pada masyrakat di pulau Lombok yang sudah dibuktikan pasca gempa Lombok 2018. Terakhir kearifan menggunakan kentongan bambu sebagai sarana peringatan dan pemberitahuan terhadap sesuatu yang terjadi sehingga peringatan dini bencana dapat diteruskan secara cepat. Ini adalah sebagian kearifan lokal masyarakat Lombok yang sangat berperan dalam mitigasi bencana gempabumi yang tiba-tiba dapat terjadi [3].

Berkaitan dengan mitigasi bencana, pemerintah telah mengeluarkan kebijakan dalam bentuk undang-undang no. 24 tahun 2007 tentang penanggulangan bencana. Undang-undang ini menjadi pedoman penyelenggaraan penanggulangan dan mitigasi bencana bagi pemerintahan daerah sampai pada tingkat kecamatan, kelurahan dan desa. Pemerintahan kecamatan, kelurahan dan desa diharapkan aktif memberikan informasi kepada pemerintahan daerah tentang kondisi daerahnya dan ancaman bencana yang mungkin muncul. Hal ini penting untuk kesiapsiagaan bencana sehingga mampu meminimalisir dampak negatif dari bencana yang terjadi. Masyarakat sekolah yang terdiri dari guru, peserta didik dan pegawai sekolah merupakan salah satu yang terdampak bila terjadi gempabumi. Apalagi bila gempabumi terjadi saat pembelajaran di kelas sedang berlangsung. Kelas adalah tempat berkumpulnya sejumlah peserta didik dalam ruang yang terbatas, sehingga dibutuhkan manajemen mitigasi bencana di kelas dan sekolah tersebut [4]. Kebijakan penanggulangan bencana sebaiknya juga diterapkan pada sekolah. Sekolah sebagai wadah dalam mewariskan kearifan lokal yang ada di masyarakat merupakan kementerian yang utama yang dapat mensosialisasikan kebijakan penanggulangan dan mitigasi bencana ini. Kearifan lokal merupakan warisan leluhur bagi generasi penerus supaya dapat dilestarikan nilai dan budayanya serta diterapkan dalam kehidupan sehari-hari [4]. Termasuk kearifan lokal Lombok yang berkenaan dengan mitigasi bencana gempabumi. Observasi yang dilakukan di SD Negeri 6 Mataram tentang bentuk-bentuk kearifan lokal Lombok tentang mitigasi bencana gempabumi banyak yang tidak dipahami oleh peserta didik. Indikatornya banyak pertanyaan-pertanyaan yang berkaitan kearifan lokal Lombok tentang mitigasi bencana gempabumi yang tidak dapat dijawab oleh peserta didik. Mereka seolah-olah tidak mengenal beberapa kearifan lokal Lombok tentang kebencanaan yang ada di sekitarnya. Padahal kedudukan kearifan lokal kebencanaan penting dan berpengaruh dalam menjalani kehidupan, terutama di daerah rawan bencana. Bila kearifan-kearifan itu tidak diwariskan dan dilestarikan pada generasi penerus yang sebenarnya peserta-peserta didik yang ada disekolah, maka siapa lagi yang akan menjaganya. Pertanyaan yang memiliki urgensi tinggi dan membutuhkan jawaban melalui kebijakan yang bersifat implementatif dan antisipatoris.

Kebijakan mengenai penanggulangan bencana memang telah tertuang dalam Undang-Undang Nomor 4 Tahun 2007. Namun, fakta di lapangan menunjukkan banyaknya kendala dalam 
mengimplementasikan kebijakan tersebut. Permasalahan ini juga ditemukan di lembaga pendidikan di tingkat sekolah. Banyak sekolah yang masih kebingungan dalam menyikapi kebijakan ini. Sebenarnya hal ini dapat diatasi dengan mengintegrasikan kearifan lokal dalam proses pembuatan kebijakan. Misalnya, kearifan lokal dalam bentuk musyawarah yang ada di masyarakat Lombok. Sekolah bermusyawarah dengan warga masyarakat atau bekerja sama dengan kantor desa dalam rangka mencari solusi atas permasalahan mengenai kebencanaan berdasarkan nilai-nilai atau kearifan yang telah ada di masyarakat [5]. Baik masyarakat maupun sekolah dapat mengungkapkan masalahmasalah apa saja yang ada terkait dengan bencana gempabumi. Sebagai masyarakat yang tinggal di kawasan rawan bencana tentu sudah memiliki wawasan yang terkait dengan kegempaan. Hal itu kemudian dapat dimusyawarahkan untuk mendapatkan solusinya. Lembaga pendidikan dapat menggali dan kemudian mengintegrasikannya dalam proses belajar mengajar di sekolah. Dengan demikian, antara lembaga pendidikan dengan masyarakat memiliki keselarasan dan dapat berjalan beriringan sehingga sekolah juga lebih mudah dalam mencapai tujuannya [6]. Apa saja kearifankearifan lokal tentang kebencanaan yang ada di masyarakat Lombok dan bagaimana bentuk kebijakan sekolah terkait dengan mitigasi bencana yang berbasis kearifan lokal menjadi pertanyaanpertanyaan yang akan dicari jawabannya melalui penelitian ini.

\section{METODE PENELITIAN}

Mengungkapkan mitigasi bencana gempabumi berbasis kearifan lokal di sekolah dasar negeri 6 Mataram ini, digunakan penelitian kualitatif deskriptif. Tujuannya adalah mendapatkan data mitigasi bencana berbasis kearifan lokal, [7]. penelitian kualitatif adalah penelitian yang berlandaskan pada filsafat postpositivisme yang biasa digunakan untuk meneliti pada kondisi objektif yang alamiah dimana peneliti berperan sebagai instrumen kunci. Penelitian kualitatif pada hakikatnya adalah mengamati orang dalam lingkungannya, berinteraksi dengan mereka, berusaha memahami bahasa dan tafsiran mereka tentang dunia sekitarnya [7], dengan demikian penelitian ini bertujuan untuk memperoleh pengertian dan pemahaman tentang suatu peristiwa atau perilaku manusia dalam suatu organisasi atau institusi. Jenis penelitian ini, menggambarkan kondisi apa adanya, tanpa memberikan perlakuan atau manipulasi pada variabel yang diteliti yang lebih mmenekankan makna pada hasilnya. Data diperoleh dari sumber data yaitu perangkat sekolah yang terdiri dari kepala sekolah, 15 guru, 25 peserta didik kelas $\mathrm{V}$ dan 1 penjaga sekolah. Pengumpulan data dilakukan dengan teknik wawancara mendalam, yaitu salah satu teknik pengumpulan data dengan mengajukan pertanyaan kepada sumber data terkait mitigasi bencana gempabumi berbasis kearifan lokal secara langsung, atau lewat telepon dan video call. Data juga dikumpulkan dengan melakukan observasi, yaitu pengumpulan data lewat pengamatan dan penginderaan. Peneliti membuat laporan berdasarkan apa yang dilihat, didengar dan dirasakan selama observasi. Focus Group Discussion (FGD) dilakukan untuk mengklarifikasi data yang diperoleh supaya mendapat kebenaran dan penyelesaian terhadap keraguan yang muncul. Peneliti melakukan diskusi bersama tentang mitigasi bencana gempabumi berbasis kearifan lokal untuk mengklrifikasi dan mengetahui pandangan dan pemahaman mereka. Terakhir data dikumpulkan dengan studi dokumen yaitu dengan mengkaji dokumen-dokumen terkait mitigasi bencana gempabumi berbasis kearifan lokal di SD Negeri 6 Mataram. Dokumen tersebut dapat berupa surat, arsip foto, notulen rapat, jurnal buku harian dan lainnya.

\section{HASIL DAN PEMBAHASAN}

Kearifan lokal masyarakat Lombok yang mempengaruhi dan menentukan dalam mitigasi bencana gempabumi, adalah : (1) Keyakinan terhadap bencana gempabumi merupakan ketetapan Allah SWT. Sebagai warga pulau Lombok, menyadari mereka berada di daerah jalur gempa(ring of fire) yaitu pada pertemuan 3 lempeng kerak bumi, yaitu; lempeng Erasia; lempeng Indo-Australia; dan lempeng Pasifik. Akibat tumbukan ketiga lempeng ini, menimbulkan jalur gempabumi yang dapat terjadi kapan saja. Hasil penelitian berdasarkan pengumpulan data dari kepala sekolah, guru, peserta didik dan penjaga sekolah sepakat bahwa bencana gempabumi hanya Allah SWT yang 
mengetahui waktu, tempat dan besarnya, sehingga merupakan ketetapan dari Allah SWT, meskipun alasan dari masing-masing berbeda-beda. Berikut ungkapan dari salah seorang guru di SD Negeri 6 Mataram.

tinggal di wilayah banyak gempa menurut saya suatu hal yang patut disyukuri karena kita akan selalu ingat pada kekuasaan Allah SW'T, sehingga menambah keimanan dan ketaqwaan kita padaNYA ( bu guru Ndk)

begitu pula pendapat dari bapak guru AGNG yang mengatakan:

gempabumi 2018 menyadarkan kita, bahwa kita tidak ada apa-apanya dibandingkan kekuasaan Allah SWT, semua hancur rata dengan tanah dalam sekejap mata. Ini adalah takdirnya tiada satupun yang bisa mengahalanginya

(2) Mitos telaga lindur, kesadaran akan pentingnya hidup berdampingan dan harmonis dengan alam untuk menghindari terjadinya bencana. Gempa dahsyat 7,0 SR pada tahun 2018 berakibat kerusakan sangat parah sebagian besar rumah warga dan menimbulkan ratusan korban jiwa. Sebelumnya pernah terjadi gempa serupa pada tahun 1980, artinya terdapat siklus gempabumi besar di Lombok sehingga dimasa yang akan datang ada kemungkinan terjadi lagi. Masyarakat Lombok melihat suatu peristiwa bencana gempabumi dari perspektif pengetahuan lokal. Pendapat lokaq (tokoh adat/pemimpin adat) tentang kebencanaan yaitu "mitos telaga lindur" [3], [6]. Mitos telaga lindur merupakan mitos yang menceriterakan tentang peristiwa bencana gempa bumi di Gumi Sasak, khususnya di Lombok Utara, sehingga menjadi menarik untuk dikaji mengenai mitigasi bencana di Lombok Utara. Mitos telaga lindur ini sangat erat kaitannya dengan kejadian gempa bumi yang pernah terjadi sebelumnya dan memiliki pesan leluhur yang belum mengetahui makna mitos telaga lindur, jika makna mitos telaga lindur terurai satu persatu, maka mitos telaga lindur menjadi pedoman dalam menyikapi gempa bumi dengan kearifan lokalnya [2]. Dengan demikian, penelitian mitos telaga lindur ini sebagai bentuk khazanah pengetahuan tradisi yang masih hidup di kalangan masyarakat yang dapat dijadikan sebagai model antisipasi bencana sebelum terjadinya bencana alam, dan dapat dijadikan sebagai acuan tata ruang pembangunan menggunakan tanda-tanda alam (subawe) sebelum membangun rumah. Makna dibalik mitos telaga lindur, memberikan pesan mengenai harus menjaga dan melindungi alam ini dengan harmonis. Hasil penelitian mendapatkan masyarakat sekolah menyikapi bencana gempabumi sebagai fenomena alam yang harus dicermati dan diterima sebagai bagian kehidupan sehingga harus diperlakukan dengan baik. Ini sejalan dengan kearifan lokal telaga lindur yang mengajarkan keharmonisan manusia dengan alam sekitar, (3) tanda fisik dan metafisik akan terjadinya bencana gempabumi, berbagai cerita, pengetahuan, pengalaman, dan tanda-tanda alam telah diwariskan antar generasi tentang tanda-tanda akan terjadinya bencana gempabumi. Hasil penelitian mendapatkan tanda-tanda fisik akan terjadinya bencana gempabumi adalah hewan hewan di daerah itu resah dan gelisah di kandangnya, suhu udara meningkat, awan berbentuk lurus, kadang muncul kilatan cahaya dari dalam tanah. Tanda metafisik biasanya dialami oleh orang-orang tertentu yang mendapatkan firasat-firasat melalui mimpi, bisikan, suara atau datangnya orang asing di pemukiman yang tiba-tiba menghilang. Tanda fisik dan metafisik ini kadang bisa benar atau kadang pula bisa salah. Tapi sisi baiknya adalah masyarakat sekolah mempunyai kesiapsiagaan dalam menghadapi bencana dan melakukan mitigasi, (4) musyawarah perangkat sekolah dengan masyarakat sekitar dalam pemecahan mitigasi bencana, musyawarah dan mufakat sebagai salah satu warisan leluhur bangsa juga sangat membumi di Lombok. Hasil penelitian menemukan perangkat sekolah mengadakan pertemuan dengan warga masyarakat di balai desa atau sekolah. Diskusi mengenai perumusan kebijakan mitigasi, dan implementasinya pada pembelajaran, (5) gotong royong saat bencana dan pasca bencana, hasil penelitian menunjukkan masyarakat Lombok sudah membuktikan bahwa gotong royong dapat mengatasi permasalahan mitigasi bencana pada gempa Lombok 2018, seperti mengangkat barang-barang ke pengungsian, mendirikan tenda, menyediakan 
makanan, mendirikan rumah darurat, tempat kesehatan dan lainnya, (6) kentongan bambu sebagai peringatan bencana, hasil penelitian menemukan masyarakat Lombok memiliki alat tradisional sebagai tanda peringatan bila terjadi bencana. Alat tersebut adalah kentongan yang terbuat dari bambu. Kentongan sebagai alat bunyi-bunyian yang dibuat dari bambu dan dibunyikan dengan cara dipukul [9]. Kentongan dibunyikan saat masyarakat harus waspada dan mempersiapkan diri untuk mengungsi dan menyelamatkan diri [10], (7) desain rumah adat Lombok untuk mitigasi bencana, terbuat dari kayu, anyaman bambu, sehingga ringan kokoh, kuat, dan tahan akan guncangan dan atap rumah terbuat dari alang-alang yang bentuknya menyerupai gunungan sehingga tahan dengan guncangan gempabumi sampai dengan 7,0 SR seperti saat gempa 2018 silam. Kearifan lokal mitigasi bencana masyarakat Lombok ini diimplementasikan oleh sekolah dasar negeri 6 Mataram. Sekolah ini, pada gempa 2018 silam merupakan sekolah yang terdampak gempa dengan kategori sedang, sehingga dalam pembangunannya ke depan akan memperhatikan kearifan lokal masyarakat Lombok tentang mitigasi bencana. Adapun implementasi mitigasi bencana di sekolah dasar negeri 6 Mataram adalah : 1) Struktural, a) konstruksi bangunan sekolah. Setelah bencana gempabumi 2018, sd negeri 6 Mataram melakukan perbaikan gedung yang didasarkan kearifan lokal dengan konstruksi gedung seperti penyediaan area terbuka di dalam lingkungan sekolah yang dapat digunakan sebagai titik kumpul bila terjadi bencana, halaman sekolah dibuat datar dan kemiringan yang landai untuk memudahkan dan meminimalisir proses evakuasi, gerbang sekolah yang lebar juga untuk memudahkan proses evakuasi dan kemudian desain pintu kelas yang membuka kebagian luar sesuai standar desain bangunan dikawasan bencana.
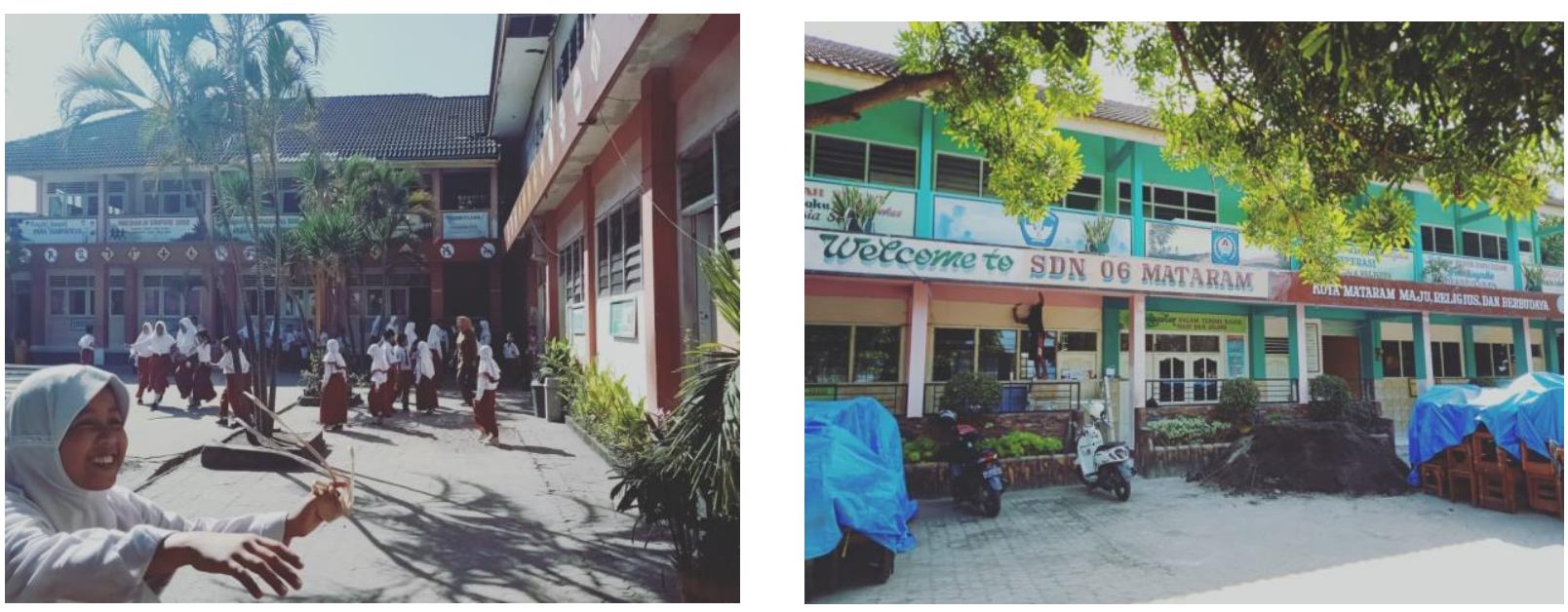

Gambar 1 : Ruang terbuka sebagai titik kumpul di SD N 6 Mataram

b) informasi kebencanaan di sekolah melalui mading, poster, spanduk dan lainnya. Sebagai contoh di SD Negeri 6 Mataram, mading digunakan sebagai media informasi gempabumi dan pengetahuan kebencanaan lainnya. Peta evakuasi, titik kumpul dan denah sekolah juga ditempelkan pada dinding sekolah sehingga memudahkan proses mitigasi bencana gempabumi. 

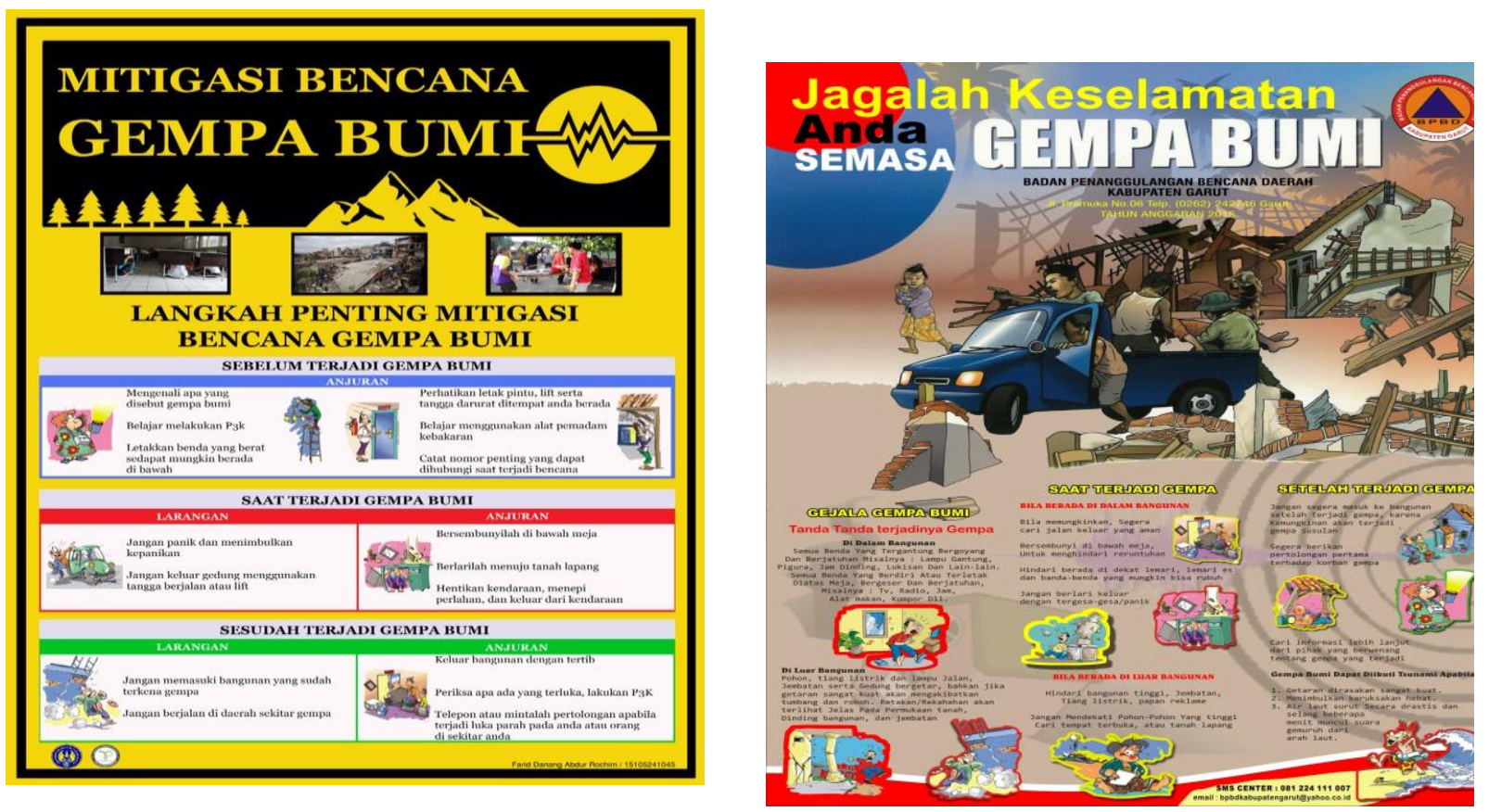

Gambar 2 : Contoh poster mitigasi gempabumı yang dıpasang d1 sekolah [ర].

2) Non struktural, a) sosialisasi, kegiatan sosialisasi mitigasi bencana gempabumi diintegrasikan ketika pertemuan orang tua atau wali murid, pembagian brosur mitigasi bencana pada peserta didik, dan pada saat upacara bendera saat amanat pembina upacara. Penyampaian sosialisasi tidak dijadwalkan secara khusus dalam suatu kegiatan. Ini didasari pada dimensi kearifan yang ada di masyarakat berupa perkumpulan sebagai wadah sekolah dalam melaksanakan sosialisasi mitigasi bencana, b) pengintegrasian mitigasi bencana gunungapi pada pembelajaran di kelas, hal ini dimaksudkan untuk meningkatkan kesiapsiagaan bencana pada peserta didik di SD Negeri 6 Mataram. Kegiatan pengintegrasian mitigasi bencana pada pembelajaran di SD Negeri 6 Mataram dalam dilihat pada video dengan link youtube https://www.youtube.com/watch? $\mathrm{v}=\mathrm{TIKA0ga2vJ8 \& \textrm {t } = 1 8 \mathrm { s }}$. Pada video ini, juga dilakukan simulasi mitigasi bencana gempabumi bila terjadi saat peserta didik belajar di kelas. Simulasi dapat meningkatkan kesiapsiagaan peserta didik dalam menghadapi bencana [11], c) Koordinasi antara sekolah dengan lingkungan sekitar, letak sekolah yang berada ditengah-tengah lingkungan masyarakat memerlukan koordinasi yang baik saat bencana. Koordinasi ini sangat diperlukan mengingat kompleksnya permasalahan yang muncul saat itu, koordinasi dapat dilakukan dengan musyawarah yang rutin dilakukan dengan masyarakat sekitar. Hal ini sesuai dengan kearifan lokal masyarakat Lombok yang membumikan musyawarah dan mufakat dalam menyelesaikanj masalah. Implementasinya adalah gotong royong dalam melakukannya. Semoga kearifan lokal masyarakat Lombok tentang mitigasi bencana dapat terus dibumikan pada masyarakat sekolah maupun masyarakat sekitarnya. Kearifan lokal diwariskan secara turun temurun kepada anak cucu dengan atau secara alami [12].

\section{KESIMPULAN}

Kearifan lokal masyarakat Lombok terhadap mitigasi bencana gempabumi adalah : (1) keyakinan bencana gempabumi adalah ketetapan dari Allah SWT, (2) mitos telaga lindur yang menimbulkan kesadaran pentingnya hidup berdampingan dan harmonis dengan alam untuk menghindari terjadi bencana, (3) tanda fisik dan metafisik, (4) musyawarah dan mufakat, (5) gotong royong, (6) kentongan bambu, dan (7) desain rumah adat Lombok untuk mitigasi bencana. Kearifan lokal ini memberikan inspirasi bagi mitigasi bencana gempabumi di sekolah. Implementasinya adalah: (1) desain bangunan di sekolah, (2) informasi kebencanaan melalui mading, poster, spanduk dan lainnya. 
Dalam bentuk non struktural dilakukan : (1) sosialisasi, (2) integrasi materi mitigasi bencana gempabumi pada pembelajaran di kelas, (3) koordinasi antara sekolah dengan lingkungan sekitar. Jadi kearifan lokal yang dimiliki masyarakat Lombok berdampak positif terhadap mitigasi bencana gempabumi di pulau Lombok

\section{UCAPAN TERIMA KASIH}

Terimakasih penulis ucapkan kepada LPPM Universitas Mataram yang telah memfasilitasi terlaksananya penelitian ini, SD Negeri 6 Mataram yang memberikan kesempatan kepada peneliti untuk melakukan kegiatan penelitian di sekolah. Guru-guru, peserta didik dan penjaga sekolah yang sudah banyak memberikan konstribusi pada penelitian ini. Terakhir, terima kasih pada Kepala Sekolah SD Negeri 6 Mataram atas kerjasamanya yang tiada henti. Semoga penelitian ini bermanfaat buat kemajuan pengetahuan mitigasi bencana.

\section{DAFTAR PUSTAKA}

[1] Masnun, 2019, "Melestarikan Kearifan Lokal Gumi Sasak", dipetik tanggal 13 Februari 2019, dari https://www.antaranews.com/berita/797826/melestarikan-kearifan-lokal-gumi-sasak

[2] Fauzan Ahmad dan Aziz Abdul L., "Kearifan Lokal tentang Mitigasi Bencana di Kabupaten Lombok Utara dalam Mitos Telaga Lindur", Jurnal Ilmiah Ilmu Sosial, vol. 6, no. 2, pp. 184-190, 2020, http://dx.doi.org/10.23887/jiis.v6i2.29941

[3] Fauzan, "Mitologi Asal Usul Orang Sasak (Analisis Struktural Pemikiran Orang Sasak dalam Tembang Doyan Neda), Tesis Antropologi, Yogyakarta: UGM, 2013, pp. 67-89

[4] Ajuba, B, P., 2015, "Studi Kebijakan Mitigasi Bencana Gunungapi Berbasis Kearifan Lingkungan di SDN Ngablak Srumbung Magelang”, Program Studi Kebijakan Pendidikan Universitas Negeri Yogyakarta.

[5] Ahimsa Putra, H. S., "Strukturalisme Levi-Strauss, Mitos Karya Sastra”, Yogyakarta: Kepel Press,2006, pp 57-150

[6] Ahimsa Putra, H.S., "Etno Bencana: Etnosains untuk Kajian Bencana”, Yogyakarta: PT. Mizan Pustaka dan CRSC UGM, 2012, pp 47-112

[7] Sugiyono, “ Metode Penelitian Pendidikan: Pendekatan Kuantitatif, Kualitatif, dan R\&D”, Bandung: Alfabeta, 2013, pp. 45-58.

[8] Danang, F., 2020, "Poster Mitigasi Bencana", dari https://www.google.com/search?q=poster+mitigasi+bencana + gempabumi + di + sekolah\&tb $\underline{m}=$ isch\&ved=2ahUKEwj 9dSzod7vAhX1BbcAHZLnDfIQ2-

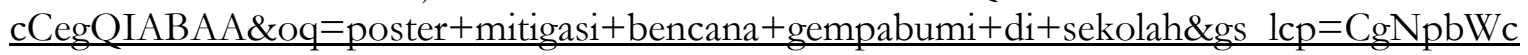
QA1Dp4AhYoIQJYMKHCWgAcAB4AIABtQGIAfUKkgEEMC4xMJgBAKABAaoBC2d3c y13aXotaW1nwAEB\&sclient=img\&ei=e19mYL MKvWL3LUPks-

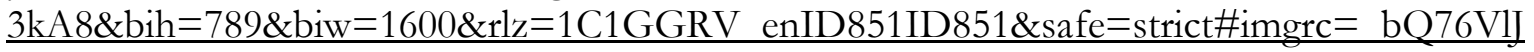
$\underline{\text { Wy FOM }}$

[9] Bramasta Dhi dan Irawan Dedy, "Mitigasi Bencana Gunung Meletus di Sekolah Rawan Bencana", Jurnal Publikasi Pendidikan, vol.10, no.2, pp. 154-159, 2020, https://doi.org/10.26858/publikan.v10i2.13858 
[10] Rahma Aldila, “Implementasi Program Pengurangan Resiko Bencana (PRB) Melalui Pendidikan Formal", Jurnal V aridika, vol. 30, no. 1, pp. 1-11, 2018, https://doi.org/10.23917/varidika.v30i1.6537

[11] Nugroho Agung, "Pengembangan Model Pembelajaran Mitigasi Bencana Gunung Meletus di Sekolah Dasar Lereng Gunung Slamet", Jurnal Pengabdian Masyarakat Multidisiplin, vol.1 no.2, pp. 50-56. 2018, https://doi.org/10.36341/jpm.v1i2.413

[12] Fauzan, "Mitologi Asal Usul Orang Sasak (Analisis Struktural Pemikiran Orang Sasak dalam Tembang Doyan Neda), Tesis Antropologi, Yogyakarta: UGM, 2013, pp. 67-89 